\title{
ЕВОЛЮЦІЯ ВИКОРИСТАННЯ НЕМАТЕРІАЛЬНИХ ІНСТРУМЕНТІВ ЕКОНОМІКИ ПРИРОДОКОРИСТУВАННЯ
}

\author{
П.М. Скрипчук \\ доктор економі чних наук, професор \\ Національний університет водного господарства та природокористування \\ (Україна, м. Рівне, e-mail: petroskrypchuk@gmail.com)
}

Макроекономічні індикатори не враховують прочесів деградачї навколишнъого природного середовища (НПС) у всіх їх проявах, що не сумісно із впровадженням положень "зеленої" економіки. Доведено, що ситуаиія з антропогенезом лише ускладнюється, а відтак постійно діючих незмінних єдиних правил, законів, директив, стандартів $і$ значенъ ГДК для всіх територіальногосподарсъких систем встановити неможливо. Виділено стадї̈ еволюиї̈ екологічних потреб унаслідож постійного збільшення антропогенного навантаження на НПС. Доведено, що узагальнюючою характеристикою економіко-екологічної системи є інтегральний показник економіко-екологічної ефективності виробництва, що всебічно відображає результативність виробництва з урахуванням збереження довкілля.

Запропоновано показники, що класифікуютвся за різними об'єктами, за характером використання, видами діяльності, змістом, ступенем агрегування та періодом аналізу. Для вирішення питань рачіонально природокористування дочільно використовувати інтегральні, комплексні показники та системний підхід, який відображається у проиедурі екологічного аудиту та завершується екологічною сертифікаиією об'єктів НПС, природно-господарсъких систем та у сфері природокористування. Систематизовано методи і методики у сфері природокористування на регіональному та локальному рівнях для екологічної сертифбікаиї̈. Доведено, що перевагою такого підходу є можливість використання локальних, максимально узгоджених показників та індикаторів, спеииббічних для кожної країни.

Використання екологічних, санітарних, гігієнічних нормативів, загалом, не допускає елементів штучності, властивих ГДК. Тому екологічне управління та його інструмент, яким є екологічна сертибіккація, має перейти від корегуючого підходу до превентивного приниипу, тому що деградаиійні проиеси відбуваються у світовій- та економіках окремих держав щодо сировини, енергоносї̈в, території як ресурсу тощо.

Обг рунтовано, що об' єктивні закони розвитку економіки неминуче призводять до інтегрованих показників, зокрема в екологічній сертифікацї, що спричиняє найвищій якості продукиї, послуг, загалом НПС, і може бути досягнуто на извому історичному етапі. Завдяки індикаторам, як-от нормативна складова, та інструменту екологічного управління суспільство має можливість свідомо керувати еколого-економічним розвитком країни та їі регіонів.

Ключові слова: індикатори, інтегральний показник, природно-господарсъкі системи, природокористування, стабілізація стану НПС, екологічна сертибікація, методика.

Постановка проблеми. Домінування панування у світі економічних, монопольних інтересів транснаціональних корпорацій, споживацької моралі у більшості людей та керівництв держав, не екологічного способу виробництва і споживання, надмірна експлуатація природноресурсного потенціалу, порушення параметрів НПС унаслідок антропогенного навантаження порушує збалансованість соціо-еколого-економічного розвитку у всіх країнах більшою (інколи критичною) або меншою мірою.

Сучасна цивілізаційна коеволюція біосфери, соціо- і техносфери у ноосферу стала реальністю. Серед негативних наслідків такого розвитку є вже набуті негативні біосфрерні, індуковані техногенезом процеси. Для іх обліку та, головне, спрричинених наслідків, світова наукова спільнота понад 50 років здійснює розробку інтегрованих, системних, сукупних, комплексних показників для вивчення й прогнозування майбутнього стану НПС на різних рівнях. Безперечно, такі процеси стосуються різних рівнів і всіх країн через закони екології, аксіоми економіки природокористування та синергетики. Традиційні макроекономічні індикатори (ВВП, ВНП) не враховують процесів деградації НПС у всіх їх проявах, що доведено вченими ріних наукових шкіл екологічної економіки, «зеленої» економіки, фрізичної економіі.

Натепер і концепція сталого розвитку зазнає критики через її теоретичність, відсутність 
універсальних та системних економічних механізмів та інструментів як для окремих країн, так і загалом територій у світовому масштабі. До того ж ситуація з антропогенезом дедалі лише ускладнюється, а відтак не може бути постійно діючих, незмінних правил, законів, директив, стандартів і значень ГДК для всіх територіально-господарських систем.

Аналіз останніх досліджень і публікацій. У контексті впровадження «зеленої» економіки в Україні актуальним є наукове обгрунтування оцінки, обробки інформації, систематизації наукових розробок, способів і шляхів досягнення цілей стабілізації стану НПС та екологізації економіки на різних рівнях.

Вагомий внесок у дослідження соціо-еколого-економічної ефективності використання нематеріальних інструментів економіки природокористування, екологічних чинників під час економічного обгрунтування господарських рішень зроблено вітчизняними вченими, серед яких I. Александров, Н. Андрєєва, О. Балацький, О. Веклич, Л. Гринів, Л. Мельник, M. Мельникович, О. Прокопенко, I. Синякевич, М. Хвесик, В. Кравців, Л. Руденко, Л. Загвойська, В. Парпан, С. Стойко, I. Соловій та ін. [1-4].

Різні аспекти антропогенного навантаження, перетворення НПС у антропогенні ландшафрти, індикатори та методики для вивчення ступеня перетвореності довкілля, моніторинг стану НПС щодо обліку екологічних та техногенних чинників вивчали провідні зарубіжні вчені (Y. Ahmad, S. El Serafy, E. Lutz, J. Hartwick, J. Stiglitz, D. Kobus, W. Nordhaus, J. Tobin, E. Barbier, A. Markandya, C. Fisher, C. Withagen, M. Toman, M. Chevé та ін.) [5-15]. Також еколого-економічні концепції розвитку глобальної економіки, критичний природний капітал, вичерпність природних ресурсів, облік різних видів забруднення, економічне зростання та інвестиції в «зелені» технології, проблеми змін клімату, рівні стійкості природних систем, можливість стабілізації антропогенного навантаження та ідентифікація мінімального і максимального рівнів змін у НПС розролено у працях інших відомих вчених [16-24].

Виділення невирішених раніше частин загальної проблеми. Одним 3 напрямів є вивчення складних соціо-екологічних систем, де особливу увагу приділено добробуту людей та екологічній стійкості самих екосистем. У своїх працях вчені (Costanza, Daily, Löffler, Nassl, Nijnik) наголошують, що природні peсурси значно впливають на добробут людини, створюючи комфортні умови життя, але це спричиняє трансорормації екосистем. Також відбувається конкретизація і спеціалізація у вивченні екосистемних процесів, наприклад, сорормовано систему індикаторів оцінювання соціо-еколого-економічного розвитку гірського регіону Карпат та доведено, що природно-господарська специфіка регіону обумовлює потребу застосування, окрім загальних, специфічних для регіону індикаторів [25].

Постановка завдання. Напрацювання індикаторів моніторингу, оцінки, інформування суспільства проходять значну еволюцію від ВВП до більш конкретних спеціалізацій й конкретних потреб. Фактично, у більшості наукових розробок використовують індикатори як характеристику процесу чи системи, за допомогою яких можна кількісно та якісно оцінювати зміни, що відбуваються, у зручній для порівняння та аналізу формі. Проведений аналіз наукових розробок засвідчує потребу в індикаторах різного рівня. Наприклад, для локальної екосистеми — це біоіндикація стану рослин за кольором листка, а відтак, стану грунтового покриву й використовуваної технології. За інших потреб - це показник, кількісний чи якісний, який відображає економічний, соціальний, екологічний розвиток у певному регіоні, громаді, місті, країні. Індикатори дають можливість вимірювати ступінь антропогенного тиску на НПС і визначати нові цілі та завдання.

Матеріали та методи досліджень: теоретичного узагальнення, системного аналізу і синтезу (для комплексної характеристики індикаторів стану держав і для ідентифрікації ї як економічної категорії); логіко-історичного (для вивчення еволюції становлення індикаторів та комплексних показників); системного підходу (для розкриття сутності комплексних показників та особливостей їх використання); термінологічного аналізу (для формування понятійного апарату дослідження); абстрагування та фрормалізації (для обгрунтування детермінантів врахування комплексних показників, теоретичного узагальнення і фрормулювання висновків).

Викладення основного матеріалу. Наразі індикатори сталого розвитку, що відображають соціальні, економічні і екологічні параметри у єдиному комплексі, є визначеними. Проте такі показники необхідно розглядати через зміну станів, кожен з яких характеризується визначеною сталістю і здатністю до змін.

Систему індикаторів Організації економічного співробітництва та розвитку (ОЕСР) розроблено відповідно до підходу «тиск - стан - реакція». Комісія ООН зі сталого розвитку виділяє чотири підсистеми єдиної системи індикаторів сталого розвитку суспільства, що розроблялися відповідно до підходу «рушійні сили - тиск - стан - вплив - реакція», як-от: 
соціальні, економічні, екологічні та інституційні. Також на міжнародному рівні використовуються такі економічні індикатори: обмеженість системи національних рахунків, валовий внутрішній продукт, валовий національний продукт, індекс конкурентоспроможного розвитку, індекс економічної свободи, чистий внутрішній продукт, міра економічного добробуту тощо.

Індикаторами екологічної складової розвитку є: індекс екологічної сталості, «екологічний слід», показник простору довкілля, показник життя планети, індекс природності тощо.

Найбільш важливими є індекси оцінювання соціальної складової розвитку, як-от: Gini, гендерного розвитку, «валового національного щастя», «щасливої планети», сталого суспільства, якості та безпеки життя, розвитку людини та суспільства, заснованого на знаннях, бідності, Тейла, Сьюта, людської бідності, фрізичної якості життя тощо [7;26].

Наразі існують індикатори, що надають змогу інтегрально оцінити добробут з урахуванням усіх його складових, як-от: «сталий» національний дохід, вимірювач справжніх заощаджень, «зелений» ВВП, індекс сталого економічного добробуту, індикатор справжнього прогресу, індекс сталого суспільства [27-28].

3 огляду на ухвалення на Саміті ОOH зі сталого розвитку 17 глобальних Цілей сталого розвитку на період до 2030 р., Стратегія сталого розвитку «Україна - 2020» потребує актуалізації. Саме тому важливим є розробка Стратегії сталого розвитку України на період до 2030 р. з відображенням існуючого рівня науковотехнічного прогресу та екологізації фрактично всіх виробництв у економічно розвинених країнах — екологізації всіх галузей виробництва, надання послуг та систем життєзабезпечення. Нині світова спільнота від якості конкретних товарів та послуг перейшла до оцінки та потреби у екологічно безпечному НПС. Для цього почали використовувати термін «якість навколишнього природного середовища». Це поняття було впроваджено і в Україні зважаючи на загальносвітові процеси,одним з яких є розвиток положень екологічного управління [29, с. $264 ; 30-33]$.

Розвиткові напряму щодо якості НПС сприяла еволюція екологічних потреб. За результатами наших досліджень виділено стадії еволюції екологічних потреб унаслідок постійного збільшення антропогенного навантаження на НПС, а саме:

1. Розвиток засобів захисту НПС від його забруднення з метою компенсації екологічної недосконалості існуючих технологій і виробничих процесів.
2. Удосконалення виробничих процесів і технологій з метою мінімізації негативного впливу на НПС.

3. Заміна екологічно небезпечних продуктів, товарів і послуг на екологічно надійні і еорективніші з урахуванням «життєвого циклу продукції».

4. Врахування екологічних вимог у більшості галузей економіки, політики, освіти.

5. Поява теорії сталого розвитку (нові галузі виробництва, екологізація попиту, споживання виробів і послуг, які прямим та опосередкованим чином сприяють збереженню ресурсів НПС).

6. Розвиток інструментарію сталого розвитку, зокрема екологічного управління, та розвиток міжнародних стандартів, у т.ч. екологічних.

7. Соціально-економічна мотивація розвитку інновацій щодо продукції, послуг, галузей економіки.

8. Розробка стандартів щодо екологічної безпеки продуктів харчування, технологій на рівні ISO, корпорацій, держав, окремих галузей і підприємств.

9. Обгрунтування взаємозалежності екологічних, економічних та соціальних передумов формування екологічної сертифікації як інструменту розв'язання проблем якості життєзабезпечення.

10. Формування міжнародних інституцій із регулювання впливу на НПС, стандартизації і сертифікації показників якості у різних галузях виробництва, надання послуг (найбільший прогрес в Україні і світі спостерігається щодо продукції сільського господарства як чинника продовольчої безпеки людини).

11. Становлення екологічної стандартизації і сертифрікації у всіх сорерах життєдіяльності суспільства та, передусім, у системі управління природокористуванням.

12. Формування «критичної» кількості населення, яке розуміє сутність і першопричини диктату виробників різного рівня та статусу (насамперед економічно розвинених країн та, щонайменше, транснаціональних компаній) від нав' язування споживацьких тенденцій, наслідків глобалізації (теорія «чистого листа» для вирощування кон'єктурних сільськогосподарських культур, теорема Т. Рибчинського тощо).

13. Виховання фальсифікованого сприйняття довкілля та зростання «інформаційного забруднення» у засобах масової інформації, діяльності посередницьких структур, для яких предметом діяльності (джерелом доходу) є формування технократичних емоцій сприйняття чинників НПС. 
14. Подальше зростання попиту на різних рівнях як для державного, регіонального, так і приватного користування щодо екологічно безпечних територій, об'єктів НПС, земельних угідь, об'єктів рекреації, житла, продукції та певних видів природних ресурсів.

В сучасних умовах інтенсивного впливу господарської діяльності на природні екосистеми виникає потреба в системі нових еколого-економічних індикаторів (системних параметрів стану і тенденцій у НПС та стандартів управління). Інноваційним аспектом такої проблеми є необхідність встановлення раціональних для природи, а не людини, норм природокористування. Такі нормативи мають бути екологічні за своєю сутністю, давати можливість теоретичного моделювання розвитку еколого-економічних та соціальних систем в напрямі їх збалансованості. Слід зауважити, що складним об'єктом для дослідження є величина загальної економічної цінності (вартості) природних ресурсів, як-от: вартість використання (споживча вартість); вартість не використання; вартість збереження біорізноманіття; вартість сполучення, або просторова сумісність різних видів природокористування у єдиній системі.

Розробку критеріїв оцінювання стану галузей економіки, соціальної сорери, сфери природокористування наведено у низці праць, зокрема: Інституту прикладного системного аналізу НАН України [34]; В.Б. Артеменка щодо індикаторів якості життя населення регіонів [32]; M.I. Долішнього та В.С. Кравціва про використання якісної і кількісної оцінки НПС [35, с. 151-164]; Л.Г. Мельника щодо вивчення системи показників всеохоплюючого контролю стану НПС [5]; Л.М. Грановської щодо інтегральної оцінки рівня розвитку регіонів [36, с. 223-242]; Н.В. Скорик - розрахунки індексу екологічної стабільності для районів, областей і для держави [37, с. 301-307]; кількісної оцінки на основі натуральних (абсолютних і відносних) показників; М.Ф. Реймерса, методичний підхід якого враховує комбінацію функціональної та екологічної класифрікацій і базується на понятті інтегрального ресурсу [38] та ін.

Отже, узагальнюючою характеристикою економіко-екологічної системи є інтегральний показник економіко-екологічної ефективності виробництва, що найповніше відображає результативність виробництва з урахуванням збереження середовища перебування. На нашу думку, необхідно враховувати наявність різних територіальних природних ресурсів, для чого вченими створюються системи оціночних районів (наприклад, у економічній географіï), регіональні економічні оцінки щодо зміни якості земельних ресурсів.
Для екологічної сертифікації на різних рівнях доцільно використовувати показники, які класифікуються: за об'єктом оиінки: послуги, продукція, грунти, біоресурси, водні та земельні ресурси, система управління, екосистема, спосіб ведення сільськогосподарського виробництва, технології; характером використання: нормативні (наприклад, уміст забруднюючих речовин), фрактичні, індикаторні (наприклад, уміст у зерні клейковини), допоміжні (наприклад, коефіцієнт екологічної стійкості ландшафртів), регулювальні; видами діялъності: економічні, екологічні, соціальні; змістом: натуральні, вартісні; ступенем агрегування: локальні, узагальнюючі, комплексні (інтегральні); періодом аналізу: ретроспективні, на момент збору, прогнозні; видом сертиб $i$ каиїі: обов'язкові, добровільні, допоміжні.

Зокрема, систему еколого-економічних оцінок стану НПС та природних ресурсів пропонується враховувати під час розробки методології екологічної сертифрікації об'єктів HПС, у сорері природокористування завдяки створенню системного інформаційного забезпечення виконання оцінки природного капіталу у комплексі із всіма об'єктами, процесами, тенденціями та з урахуванням часового чинника. Незалежно від критеріальної основи та фрункціонального призначення, для оцінки навколишнього природного середовища певню мірою є характерним і економічний «підтекст». Це означає, що будь-які процеси «порушення» чи «поліпшення» якості НПС безпосередньо чи опосередковано обумовлено економічними втратами або вигодами, навіть якщо ці економічні показники не «уловлюються» формальною системою економічних розрахунків [38, с. 357]. На нашу думку, для вирішення таких питань раціонально використовувати інтегральні, комплексні показники та системний підхід, який відображається у процедурі екологічного аудиту та логічно має завершуватись екологічною сертифікацією об'єктів НПС, певних територій, природно-господарських систем та у сорері природокористування (рис. 1).

У сорері природокористування на регіональному та локальному рівнях для екологічної сертифікації об'єктів НПС, конкретних територій пропонується використовувати: методики тестування за допомогою живих організмів; екологічну діагностику ландшафтів (використання та інтеграція екологічних, економічних, соціальних та статистичних показників, екологічного управління, медицини, синергетики); показники сталості землекористування (Д.С. Добряк); методику комплексної оцінки екологічно проблемних регіонів (З.В. Герасимчук); вимірювання регіонального розвит- 


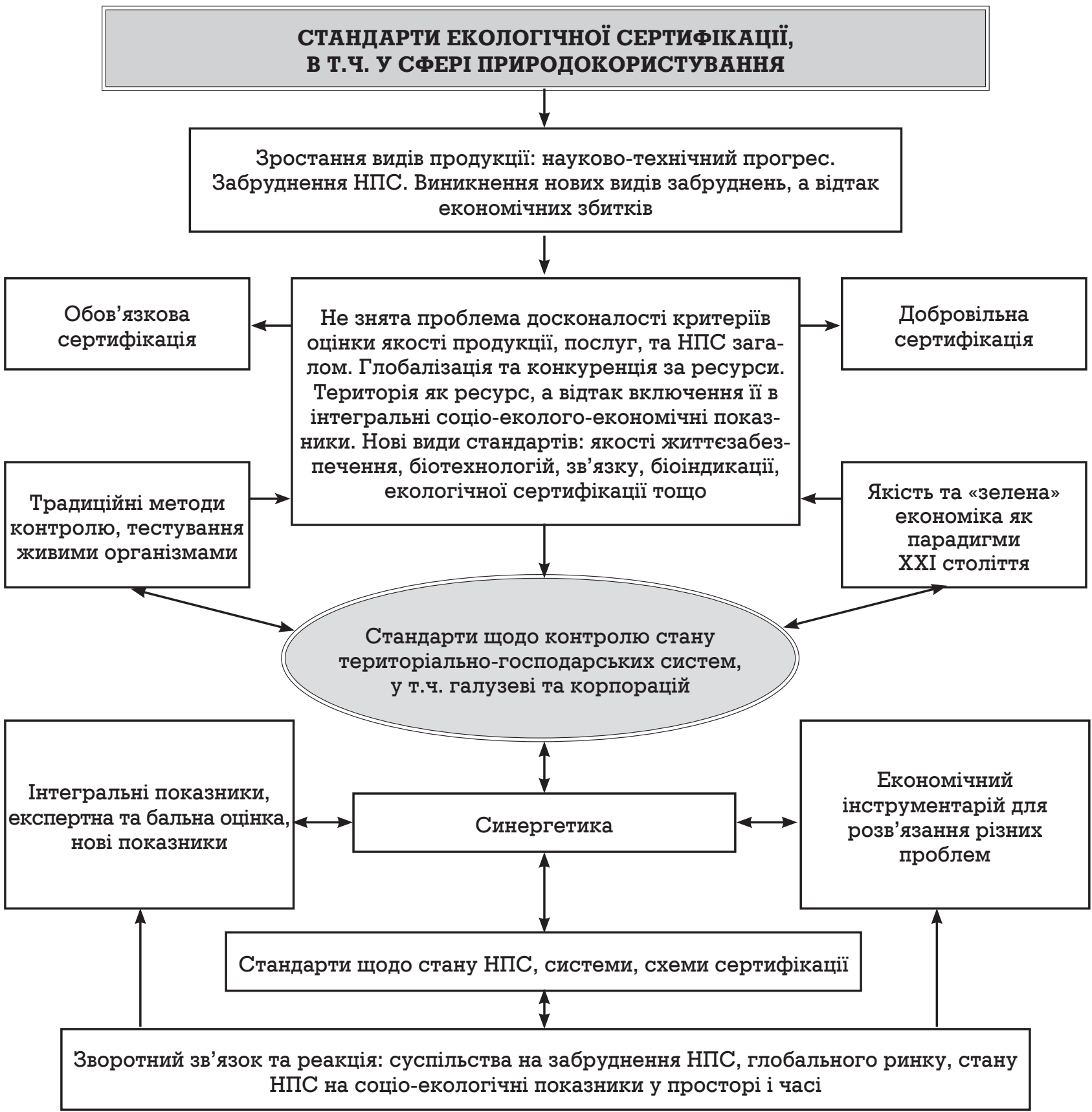

Рис. 1. Алгоритм бормування стандартів з екологічної сертифбікаиї

ку з використанням концепції якості життя (В.Б. Артеменко); екологічне нормування та оцінку безпеки НПС (М.A. Ємець, М.В. Мажаров); оцінку економіко-екологічних збитків від зниження якості життя населення (П.В. Тархов), концепцію екологічної сертифікації (П.М. Скрипчук) та ін.

Такі та інші концептуальні засади засвідчують становлення і розвиток нових методологічних підходів до системної оцінки якості НПС загалом, певних його ресурсів і територій як для бізнесу, так і для життєзабезпечення населення.

Вказані індикатори, показники, критерії використовуються під час екологічного аудиту об'єктів НПС, ландшафртів, екосистем (наприклад, лісова сертифікація), а в подальшому для екологічної сертифрікації певних територій (природно-господарських систем). Для цього за показники екологічного управління доцільно використовувати сертифіковані документи: підприємства (певна їх кількість, що 
володіє сертифікованими системами управління), об'єктів НПС, деяких територій, адміністративних районів (вимірювання доцільно проводити у балах, відсотках чи абсолютних значеннях величин). Зауважимо, що перевагою такого підходу є можливість використання: локальних, максимально узгоджених показників та індикаторів, навіть специфічних для кожної країни. Але на вищому рівні агрегування такі показники перетворюються в інтегральні. Звідси отримуємо сертифіковану одиницю території відповідно до концепції екологічної сертифікації [29].

Кількісну та якісну оцінку стану НПС та сорери природокористування проводять з використанням ГДК. Зважаючи на розвиток видів нової продукції, надання послуг, зміну антропогенного навантаження, розробники ГдК не встигають стандартизувати їх значення. Нині в Україні використовують ГдК для понад 320 речовин, які забруднюють атмосферу, 600 речовин, які забруднюють воду, та декілька десятків, що забруднюють грунти. Розробляються нормативи для комбінацій цих забруднюючих речовин. На нашу думку, натепер доцільно використовувати екологічну сертифікацію загалом для всіх видів природокористування.

Вагомою перевагою екологічної сертифікації є використання екологічних, санітарних і гігієнічних характеристик, сумарних нормативів впливу на об'єкти НПС, стандартів стану організмів і НПС, стандартів техносфери, стандартів опосередкованого впливу, чинників зворотного зв'язку і часу. Використання екологічних, санітарних, гігієнічних нормативів у сукупності виключають елементи штучності 3 ГДК, а саме:

- завдання екологічного нормування $\mathrm{\epsilon}$ захист елементів біосфери та її складових у сукупності - екосистеми, популяції. Слід зауважити, що у цьому процесі допускаються одиничні втрати особин. Для людини такі підходи - недопустимі;

- завдання санітарно-гігієнічного нормування - забезпечити безпеку людини, що не гарантує захист екосистем та НПС загалом від антропогенного забруднення. Стандарти техносорери можуть бути доречними для людини, але недопустимими для НПС, що підтверджується даними досліджень, зокрема в роботі Л.Г. Мельника [3]. Прикладом системного нормування якості є комплексна екологічна оцінка (класифікація) якості поверхневих прісних вод, що налічує сольовий склад, токсикологічні, радіаційні та трофро-сапробіологічні показники.

Екологічні індикатори, з одного боку, доводять необхідність екологізації економіки, а 3 іншого, інформують про стан НПС як єдиний інтегральний ресурс та взаємодію окремих частин системи між собою, завдяки чому вони починають діяти як єдине ціле. Таке синергетичне явище призводить до ефекту емерджентності, коли із елементів системи (об'єкти НПС та ї стан, внутрішні та зовнішні позитивні чи негативні процеси, масштаби, ступінь та характер використання тощо) фрормується нова система, яка внаслідок можливої сертифрікації (позитивний результат) володіє значно більшим екологічним, економічним, соціальним ефектом, а отже і цінністю. Тому екологічне управління та його інструмент — екологічна сертифрікація - має на меті перейти від коригувального підходу (ліквідації екологічних катастроф і проблем) до превентивного принципу (недопущення проблем, запобігання тенденціям ї появи і розвитку тощо). Такі процеси вже відбуваються у світовій- та економіці держав щодо сировини, енергоносіїв, території як ресурсу, товарів прем'єр-групи тощо.

Одним із узагальнюючих напрямів щодо соціо-еколого-економічних індикаторів є розвиток інформаційної економіки. На нашу думку, інфрормаційними продуктами інтелекту та суспільства є: закони, декларації, концепції, правила, стандарти, інструкції, інорормація, за допомогою яких людина змінює ландшафти, екосистеми, біоценози. До інорормаційних сутностей вищого рівня, наприклад, можливо віднести генетичну інорормацію про виведені людством нові біологічні види (генетично модифіковані організми та рослини). Так, стає очевидною еволюція розвитку екологічної та економічних наук щодо нормування антропогенного впливу та збереження якості НПС. Спочатку (на певному рівні) виникла необхідність стандартів, що мінімізують вплив деяких чинників на НПС (ГДК, ГДВ, ГДС тощо), а незабаром і перетворених, змінених у певний спосіб цілісних екосистем або ландшафтів (для басейну річки - коефіцієнт антропогенного навантаження, коефіцієнт екологічної стійкості ландшафтів), а загалом, для держав або регіонів - індексів сталого розвитку тощо. Через деякий час, та сама стандартизація мала вже вирішувати питання щодо: безпеки використання генетично змінених організмів як для людини, так і загалом для НПС, показників якості НПС, впливу стільникового зв'язку на здоров'я людства та врешті - сумарного впливу всіх відомих і невідомих світовій спільноті негативних чинників сьогодення на людину.

Методологічно не розробленими залишаються законодавчо-нормативні положення та методики щодо екологічного аудиту об'єктів НПС, деяких природних ресурсів, природногосподарських систем, територій населених 
пунктів - саме для них слід використовувати інтегральні показники та експертні оцінки тощо. Тому як в Україні, так і на міжнародному рівні перед партнерами законодавства в захисті НПС стоять такі завдання: розробка механізмів, що забезпечують процедури екологічного аудиту з використанням інтегрованих показників (індексів) відкритими, обгрунтованими з огляду на подальше прийняття рішень; вдосконалення систем оцінювання за допомогою інтегрованих показників об єктів НПС, що мають різну і суперечливу природу (наприклад, водні ресурси, елементи ландшафттів) на національному та міжнародному рівнях; напрацювання та стандартизація інтегрованих показників якості НПС тощо. До того ж цьому для моніторингу стану НПС доцільно використовувати процентилі як ймовірність перевищення певної концентрації речовини у відсотках. На нашу думку, як критерії екологічної сертифрікації у сорері природокористування мають бути прийняті (рис. 2):

Процедура екологічної сертифікації: екологічний аудит і врахування сумації речовин, інтегральні показники, мінімальні вимоги на регіональному рівні через процентилі для певних видів ресурсів. Види робіт із екологічного аудиту та висновок про сертифрікацію приймає аудитор. Економія коштів. Врахування динаміки соціо-еколого-економічних показників стану природно-господарських (територіально-господарських) систем

1. Для традиційного землеробства - 95\%, органічного - 98, під технічні культури (ріпак, льон, соняшник) - 80\% процентиль забруднюючих речовин. Остаточне рішення про ступінь

\section{Розробка інтегральних показників для екологічної сертифікації територіально-господарських систем}

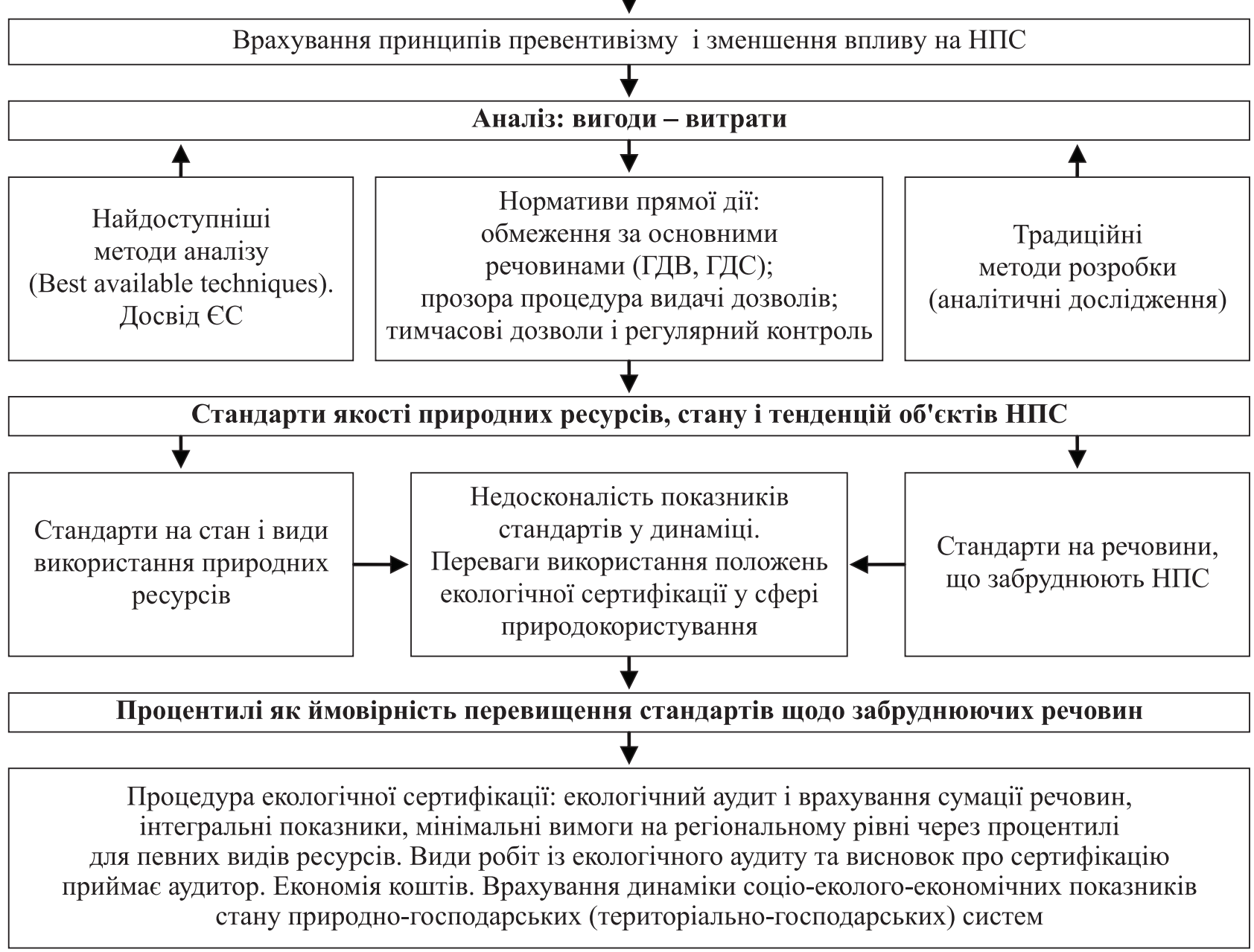

Рис. 2. Алгоритм розробки і обгрунтування інтегральних показників для екологічної сертифбікаиіï у сбері природокористування 
дієвості контролю і якість сировини та продукції приймається екологічним аудитором.

2. Для поверхневих водних ресурсів можливо використовувати критерії щодо класів якості і $90 \%$ процентиль.

3. Для викидів у атмосорерне повітря: від стаціонарних джерел у межах міста - 95\% процентиль для речовин 2-го і вищого класів (традиційні стандарти для забруднюючих речовин 1-го класу небезпеки); від стаціонарних джерел за межею міста - 90\% процентиль для речовин 2-го і вищого класів (традиційні стандарти для забруднюючих речовин 1-го класу; для пересувних джерел - 95\% для речовин 2-го і вищого класів (традиційні стандарти для забруднюючих речовин 1-го класу небезпеки).

4. Біоресурси: лісові масиви - 90\% процентиль; рослини в зонах рекреації 95; зони 3 рослинами і тваринами, що занесені до Червоної книги, та особливо охоронні території - 99; урбанізовані території із представниками біоресурсів - 80; інші території із рослинним і тваринним світом - $90 \%$ процентиль із обгрунтуванням у процедурі екологічного аудиту.

5. Для людини: діти до 15 років - 99\% процентиль щодо всіх видів негативного впливу; доросле населення - 90, у т.ч. всі види негативного впливу (традиційні стандарти для забруднюючих речовин 1-го класу небезпеки); питна вода $-99 \%$ процентиль для всіх споживачів.
6. Харчові продукти і напої: діти до 15 років - 99\% процентиль щодо всіх видів продуктів і напоїв; доросле населення - 90\% процентиль, у т.ч. всі продукти споживчого кошика (традиційні стандарти для забруднюючих речовин 1-го класу небезпеки).

У разі наявності забруднюючих речовин, яким властивий ефект сумації і підсилюючої дії, пропонується вибирати більш жорсткі значення нормативів. Отже, для екологічної сертифікації доцільно використовувати всі види чинних нормативних документів, як-от: основоположні, галузеві- та стандарти підприємств, технічні умови, директиви щодо методичного, аналітичного, метрологічного, екологічного обгрунтування економічної її доцільності. На практиці вибір способів дослідження у галузі торгівлі, послуг, на виробництві, для об'єктів НПС тощо відбувається згідно із схемами і системами сертифрікації.

Висновки. Об'єктивні закони розвитку економіки неминуче обумовлюють інтегровані показники, у т.ч. в екологічній сертифікації, що сприятимуть найвищій якості продукції, послуг і, загалом, безпеці НПС, що може бути досягнуто на нинішньому історичному етапі. Завдяки індикаторам, як-от нормативна складова та інструмент екологічного управління, суспільство має можливість свідомо керувати еколого-економічним розвитком країни та їі регіонів.

\section{СПИСОК ВИКОРИСТАНИХ ДЖЕРЕЛ}

1. Синякевич I.M., Соловій I.П., Врублевська О.В. та ін. Лісова політика: теорія і практика: [монографрія]; за наук. ред. І.М. Синякевича. Львів: ЛА «Піра-міда», 2008. 612 с.

2. Соловій І.П., Мельникович М.П. Соціо-еколого-економічна збалансованість розвитку: територіальний та секторальний аспекти / / Наукові праці Лісівничої академії наук України: збірник наукових праць. Львів: РВВ НЛТУ України, 2010. С. 193-198.

3. Мельник Л.Г. Экономика развития: [монографія]. Сумы: ИТД «Университетская книга», 2006. 662 с.

4. Гринів Л.С. Екологічна економіка. Львів: «Магнолія 2006», 2010. 360 с.

5. Індекс регіонального людського розвитку. [Електронний ресурс]. Режим доступу: http://www.idss. org.ua/ukr_index/irlr_2014.html

6. Bobylev S. Economic evaluation of environmental goods // Business Styles and Sustainable Development: 5th International Conference on Ethics and Environmental Policies (Kyiv, 2-6 April 2003). Kyiv, 2003. P. 35-37.

7. Goodwin N., Nelson J., Harris J. Macroeconomic Measurement: Environmental and Social Dimensions. A GDAE Teaching Module on Social and Environmental Issues in Economics // Global Development and Environment Institute, Tufts University. [Електронний ресурс]. Режим доступу: http://www.ase. tufts.edu/gdae.

8. Costanza R., Erickson J. The index of sustainable economic welfare (ISEW) for a local authority: A case study in Italy Federico Maria Pulselli, Francesca Ciampalini, Enzo Tiezzi, Carlo Zappia, Department of Chemical and Biosystems Sciences and Technologies, University of Siena, Received 12 May 2005 , Italy.

9. Daly H., Farley J. Ecological Economics. Principles and applications. Washington: Island Press, 2004. $454 \mathrm{p}$.

10. Farley J., Ericson J., Daly H. Ecological economics. A workbook for problem-based learning. Washington: Island Press, 2005. 215 p.

11. Kobus D. The Evaluation of Progress Towards Achieving Sustainable Development in Countries in Transition. Doctoral thesis, Faculty of Arts, University of Manchester, Manchester. 2001. 
12. Stiglitz J.E. GDP Fetishism. The Economists' Voice. The Berkeley Electronic Press. Project Syndicate, September 2009. [Електронний ресурс]. Режим доступу: http://www.bepress.com/ev

13. The 2005 Environmental Sustainability Index Report. Yale Center for Environmental Law and Policy. Yale University.2005. [Електронний ресурс]. Режим доступу: www.yale.edu/esi

14. Chevé M. Irreversibility of Pollution Accumulation: New Implications for Sustainable Endogenous Growth // Environmental and Resource Economics. 2000. № 16. P. 93-104.

15. Fisher C., Withagen C., Toman M. Optimal Investment in Clean Production Technology // Environmental and Resource Economics. 2004. № 28. P. 325-345.

16. Hediger W. Sustainable development and social welfare // Ecological Economics. 2000. № 32. P. 481492 .

17. Asako K. Economic Growth and Environmental Pollution under the Max-Min Principle // Journal of Environmental Economics and Management. 1980. № 7. P. 157-183.

18. Azar C. Long-term Environmental Problems - Economic Measures and Physical Indicators. PhD Thesis, Institute of Physical Resource Theory, Chalmers University of Technology, Göteborg University, Sweden. 1995.

19. Barbier E., Markandya A. The conditions for achieving environmentally sustainable development // European Economic Review. 1990. № 34. P. 659-669.

20. Shkuratov O. Methodology for estimation of ecological safety in the agricultural of Ukraine // Scientific Papers: Series Management, Economic Engineering in Agriculture and Rural Development. 2018. Vol. 18. Issue 3. P. 379-386.

21. Daly H.E. The economics of the steady state // American Economic Review. 1974. № 64(2). P. 15-21.

22. Fiedler K. The Conditions for Ecological Sustainable Development in the Context of a Double-Limited Selfpurification Model of an Aggregate Water Resource // Environmental and Resource Economics 1997. № 9. P. 309-321.

23. Shkuratov O., Hreshchuk H., Lobanova O. Forecast scenarios of development of the internal consumer market of organic products in Ukraine // Scientific Papers: Series Management, Economic Engineering in Agriculture and Rural Development. 2018. Vol. 18. Issue 4. P. 303-310.

24. Hediger W. Weak and strong sustainability, environmental conservation and economic growth, Natural Resource Modeling (forthcoming). 2006.

25. Мельникович М.П. Формування системи індикаторів оцінювання соціо-еколого-економічного розвитку гірського регіону Карпат: автореф. дис. ... канд. екон. наук: 08.00.06 / Національний університет водного господарства та природокористування. Рівне, 2019, 23 с.

26. Harris J.M., Codur A.M. Macroeconomics and the Environment. A GDAE Teaching Module on Social and Environmental Issues in Economics. Global Development and Environment Institute, Tufts University. [Електронний ресурс]. Режим доступу: http://www.ase.tufts.edu/gdae

27. Daly H.E., Cobb J.B. «Appendix: The Index of Sustainable Economic Welfare» in H.E. Daly and J.B. Cobb For the Common Good: Redirecting the Economy Toward Community, the Environment, and a Sustainable Future, 2nd ed. Boston: Beacon Press, 1994.

28. Talberth J., Cobb C., Slattery N. The Genuine Progress Indicator // Executive Summary. 2006. [Електронний ресурс]. Режим доступу: www.redefiningprogress.org

29. Скрипчук П.М. Організаційно-економічні засади екологічної сертифікації в системі управління природокористуванням: монографія. Рівне: НУВГП, 2012. 336 с.

30. Рівень і якість життя населення: монографія; заг. ред. С.П. Кушнарьова. Х.: Видавничий Дім «ІНЖћЕК», 2004. 272 c.

31. Купцова О.Є. Формування еколого-економічної системи життєзабезпечення на регіональному рівні: автореф. дис. ... канд. екон. наук: 08.08.01 / Інститут проблем ринку та економіко-екологічних досліджень. Одеса, 2005. 20 с.

32. Артеменко В.Б. Основи вимірювання регіонального розвитку з використанням концепції якості життя // Регіональна економіка. № 2. 2003. С. 133-141.

33. Садченко Е. В. Теоретико-методологические основы «экологизации» макроэконо-мических показателей // Ринкова економіка: Сучасна теорія і практика управління. 2004. Т. 7. (Вип. 8). С. 98-104.

34. Згуровський М.3. Сталий розвиток у глобальному і регіональному вимірах: Аналіз за даними 2005 р. К.: НТУУ «КПІ», 2006. 84 с.

35. Долішний M.І., Кравців В.С. Екологічні аспекти соціальної асиметрії українського суспільства // Проблеми сталого розвитку України. 2001. С. 151-164.

36. Грановська Л.М. Еколого-збалансоване природокористування в умовах поліфункціональності територій: монографія. Херсон: Вид-во ХДУ, 2009. 414 с.

37. Скорик Н.В. Просторові аспекти збереження біорізномаїття як економічного ресурсу // Вісник соціально-економічних досліджень. 2007. Вип. 26. С. 301-307.

38. Реймерс Н.Ф. Екология. Теория, законы, принципы и гипотезы. М.: Россия молодая, 1994.367 с. 


\section{Інформація про автора}

Скрипчук Петро Михайлович - доктор економічних наук, професор кафедри менеджменту, Національний університет водного господарства і природокористування (Україна, 33000, м. Рівне, вул. Соборна, 11; e-mail: petroskrypchuk@gmail.com).

P.M. Skrypchuk

Doctor of Economic Sciences, Professor

National University of Water and Environmental Engineering (Ukraine, Rivne; e-mail: petroskrypchuk@gmail.com)

\section{EVOLUTION OF NON-MATERIAL USE OF THE ECONOMY NATURAL INSTRUMENTS}

Macroeconomic indicators do not take into account degradation processes of the natural environment in all their manifestations, which is incompatible with the implementation of the "green" economy provisions. It is proved that the situation with anthropogenesis is only complicated - and therefore there can be no permanent rules, laws, directives, standards and values of the MPC at all times and for all territorial and economic systems. The stages of the evolution of the ecological needs are highlighted as a result of the constant increase of anthropogenic loading on the environment. It is proved that the generalizing characteristic of the economic-ecological system is an integral indicator of the economic and ecological efficiency of production, which most fully reflects the efficiency of production, taking into account the preservation of the environment.

Proposed indicators are classified according to the different objects, nature of use, types of activity, content, degree of aggregation and period of analysis. In order to address the issues of rational nature use, it is expedient to use integral, integrated indicators and a systematic approach that is reflected in the environmental audit procedure and ends with the environmental certification of environmental facilities, natural-economic systems and in the field of nature management. Systematized methods and techniques in the field of nature management at the regional and local levels for environmental certification. It is proved that the advantage of this approach is the possibility of using local, maximum consistent indicators and indicators specific to each country.

The use of environmental, sanitary, and hygienic standards collectively excludes artificial elements that are present for the MAC. Therefore, ecological management and its instrument-ecological certification, is intended to depart from the corrective approach to the precautionary principle, because degradation processes occur in the world (raw materials, energy resources, territory as a resource, etc).

It is substantiated that the objective law of economic development inevitably lead to integrated indicators including environmental certification, which is a guarantee of the highest quality of products, services and natural environment as well. Due to such indicators as a normative component and an instrument of environmental management, the society has the ability to consciously manage the ecological and economic development of the country and its regions.

Keywords: indicators, integral index, natural and economic systems, nature management, stabilization of the natural environment condition, ecological certification, methodology.

\section{REFERENCES}

1. Syniakevych, I.M. Solovii, I.P. and Vrublevska, O.V.etc. (2008). Lisova polityka: teoriya $i$ praktyka: monohrafiya [Forest Policy: Theory and Practice: monograph]; Sinyakevich I.M. (Ed.). Lviv: Pira-Mida LA. 612. (In Ukr.)

2. Solovii, I.P. \& Melnykovych, M.P. (2010). Sotsio-ekoloho-ekonomichna zbalansovanist' rozvytku: terytorial'nyy ta sektoral'nyy aspekty [Socio-ecological-economic balance of development: territorial and sectoral aspects]. Naukovi pratsi Lisivnychoyi akademiyi nauk Ukrayiny: zbirnyk naukovykh prats' [Scientific works of the Forestry Academy of Sciences of Ukraine: collection of scientific works]. 8, 193-198. (In Ukr.)

3. Melnyk, L.G. (2006). Ekonomika razvitiya: monografíya [Development Economics: monograph]. Sumy: Universitetskaya kniga. 662. (In Russ.)

4. Hryniv, L.S. (2010). Ekolohichna ekonomika [Ecological economy]. L'viv: Mahnoliya 2006. 360. (In Ukr.)

5. The Institute of Demography and Social Research named after M.V. Ptukhy (2012), «Regional Human Development Index», [Electronic source]. URL:http://www.idss.org.ua/ukr_index/irlr_2014.html (date of accesse: 27.04.2019).

6. Bobylev, S. (2003). «Economic evaluation of environmental goods». Collection of the 5th International Conference on Ethics and Environmental Policy [Business Styles and Sustainable Development] 5th International Conference on Ethics and Environmental Policies. Kyiv, Ukraine. pp. 35-37. (In Ukr.) 
7. Goodwin, N., Nelson, J. and Harris, J. (2019). Macroeconomic Measurement: Environmental and Social Dimensions. A GDAE Teaching Module on Social and Environmental Issues in Economics. Global Development and Environment Institute, Tufts University. [Electronic source]. URL: http://www.ase.tufts. edu/gdae/education_materials/modules.html (date of accesse 01.03.2019)

8. Costanza R. \& Erickson J. (2005). The index of sustainable economic welfare (ISEW) for a local authority: A case study in Italy Federico Maria Pulselli, Francesca Ciampalini, Enzo Tiezzi, Carlo Zappia, Department of Chemical and Biosystems Sciences and Technologies, University of Siena, Italy.

9. Daly, H. \& Farley, J. (2004). Ecological Economics. Principles and applications. Washington: Island Press, 454.

10. Farley, J., Ericson, J. and Daly, H. (2005). Ecological economics. A workbook for problem-based learning. Washington: Island Press. 215.

11. Kobus, D. (2001). The evaluation of progress towards achieving sustainable development in countries in transition. Doctoral thesis, Faculty of Arts, University of Manchester, Manchester.

12. Stiglitz, J.E. (2009). GDP Fetishism. The Economists' Voice. The Berkeley Electronic Press. Project Syndicate. [Electronic source]. URL: http://www.bepress.com/ev

13. The 2005 Environmental Sustainability Index Report. Yale Center for Environmental Law and Policy. Yale University. 2005. [Electronic source]. URL: www.yale.edu/esi (date of accesse 21.02.2019)

14. Chevé, M. (2000). Irreversibility of Pollution Accumulation: New Implications for Sustainable Endogenous Growth. Environmental and Resource Economics, 16, 93-104.

15. Fisher, C., Withagen, C. and Toman, M. (2004). Optimal Investment in Clean Production Technology. Environmental and Resource Economics, 28. 325-345.

16. Hediger, W. (2000). Sustainable development and social welfare. Ecological Economics, 32, 481-492.

17. Asako, K. (1980). Economic Growth and Environmental Pollution under the Max-Min Principle. Journal of Environmental Economics and Management, 7, 157-183.

18. Azar, C. (1995) Long-term Environmental Problems - Economic Measures and Physical Indicators. PhD Thesis, Institute of Physical Resource Theory, Chalmers University of Technology, Göteborg University, Sweden.

19. Barbier, E. \& Markandya, A. (1990). The conditions for achieving environmentally sustainable development. European Economic Review, 34, 659-669.

20. Shkuratov, O. (2018). Methodology for estimation of ecological safety in the agricultural of Ukraine // Scientific Papers: Series Management, Economic Engineering in Agriculture and Rural Development, $18,3,303-310$.

21. Daly, H.E. (1974). The economics of the steady state. American Economic Review, 64 (2), $15-21$.

22. Fiedler, K. (1997). The Conditions for Ecological Sustainable Development in the Context of a DoubleLimited Selfpurification Model of an Aggregate Water Resource. Environmental and Resource Economics, 9, 309-321.

23. Shkuratov, O., Hreshchuk, H. \& Lobanova O. (2018). Forecast scenarios of development of the internal consumer market of organic products in Ukraine. Scientific Papers: Series Management, Economic Engineering in Agriculture and Rural Development, 18, 4, 303-310.

24. Hediger, W. (2006). Weak and strong sustainability, environmental conservation and economic growth, Natural Resource Modeling (forthcoming).

25. Melnykovych, M.P. (2019). Formuvannia Systemy Indykatoriv Otsiniuvannia Sotsio-Ekoloho-Ekonomichnoho Rozvytku Hirskoho Rehionu Karpat [Formation of a system of indicators for assessing the socio-ecological and economic development of the Carpathian mountain region]: author's abstract. dis.... cand. econom. sciences: 08.00.06 / National University of Water Management and Environmental Management. Rivne, 2019. 23. (In Ukr.)

26. Harris, J.M. \& Codur, A.M. Macroeconomics and the Environment. A GDAE Teaching Module on Social and Environmental Issues in Economics. Global Development and Environment Institute, Tufts University. [Electronic source]. URL: http://www.ase.tufts.edu/gdae

27. Daly, H.E. \& Cobb, J.B. (1994). «Appendix: The Index of Sustainable Economic Welfare» in H.E. Daly and J.B.Cobb For the Common Good: Redirecting the Economy Toward Community, the Environment, and a Sustainable Future, 2nd ed. Boston: Beacon Press.

28. Talberth, J., Cobb, C. and Slattery, N. (2006). The Genuine Progress Indicator. Executive Summary. [Electronic source]. URL: www.redefiningprogress.org

29. Skrypchuk, P.M. (2012). Orhanizatsiyno-ekonomichni zasady ekolohichnoyi sertyfikatsiyi v systemi upravlinnya pryrodokorystuvannyam: monohrafiya [Organizational and economic principles of ecological certification in the system of environmental management: monograph]. Rivne: NUVHP. 336 (In Ukr.)

30. Kushnarova, Ye.P. (Ed.) (2004). Riven' i yakist' zhyttya naselennya [Level and quality of life of the population: monograph]. X.: Vydavnychyi Dim «INZhEK». 272. (In Ukr.)

31. Kuptsova, O.Ye. (2005). Formuvannia Ekoloho-Ekonomichnoi Systemy Zhyttiezabezpechennia Na Rehionalnomu Rivni [Formation of ecological and economic system of life support at regional level]: author's abstract. dis.... cand. econom. sciences: 08.08.01 / Institute for Market Problems and Economic 
and Environmental Research. Odesa, 2005. 20. (In Ukr.).

32. Artemenko, V.B. (2003). Osnovy vymiryuvannya rehional'noho rozvytku z vykorystannyam kontseptsiyi yakosti zhyttya [Fundamentals of measuring regional development using the concept of quality of life]. Rehional'na ekonomika [Regional Economics], 2. 133-141. (In Ukr.)

33. Sadchenko, E.V. (2004). Teoretyko-metodolohycheskye osnovy «ékolohyzatsyy» makroékono-mycheskykh pokazateley [Theoretical and methodological foundations of «ecologization» of macroeconomic indicators]. Rynkova ekonomika: Suchasna teoriya i praktyka upravlinnya [Market Economics: Modern Theory and Practice of Management], 7 (8), 98-104. (In Ukr.)

34. Zghurovskyi, M.Z. (2006). Stalyy rozvytok u hlobal'nomu i rehional'nomu vymirakh: Analiz za danymy 2005 r. [Sustainable development in the global and regional dimensions: Analysis according to 2005]. Kyiv: NTUU «KPI». 84. (In Ukr.)

35. Dolishnyi, M.I. \& Kravtsiv, V.S. (2001). Ekolohichni aspekty sotsial'noyi asymetriyi ukrayins'koho suspil'stva [Ecological aspects of social asymmetry of Ukrainian society]. Problemy staloho rozvytku Ukrayiny [Problems of sustainable development of Ukraine]. 151-164. (In Ukr.)

36. Hranovska, L.M. (2009). Ekoloho-zbalansovane pryrodokorystuvannya v umovakh polifunktsional'nosti terytoriy [Ecologically-balanced nature management in the conditions of multifunctionality of territories]. Kherson: Vyd-Vo KhDU. 414. (In Ukr.)

37. Skoryk, N.V. (2007). Prostorovi aspekty zberezhennya bioriznomayittya yak ekonomichnoho resursu [Spatial aspects of biodiversity conservation as an economic resource]. Visnyk sotsial'no-ekonomichnykh doslidzhen' [Bulletin of socio-economic research], 26, 301-307. (In Ukr.)

38. Reymers, N.F. (1994). Ekologiya. Teoriya, zakony, principy i gipotezy [Ecology Theory, laws, principles and hypotheses]. M.: Rossiya molodaya. 367. (In Russ.)

\section{Author}

Skrypchuk Petro Myhaylovich - Doctor of Economic Sciences, Professor, Professor of Department of Management, National University of Water and Environmental Engineering (Ukraine, 33000, Rivne, 11 Soborna st.; e-mail: petroskrypchuk@gmail.com).

\section{HOBEHE}

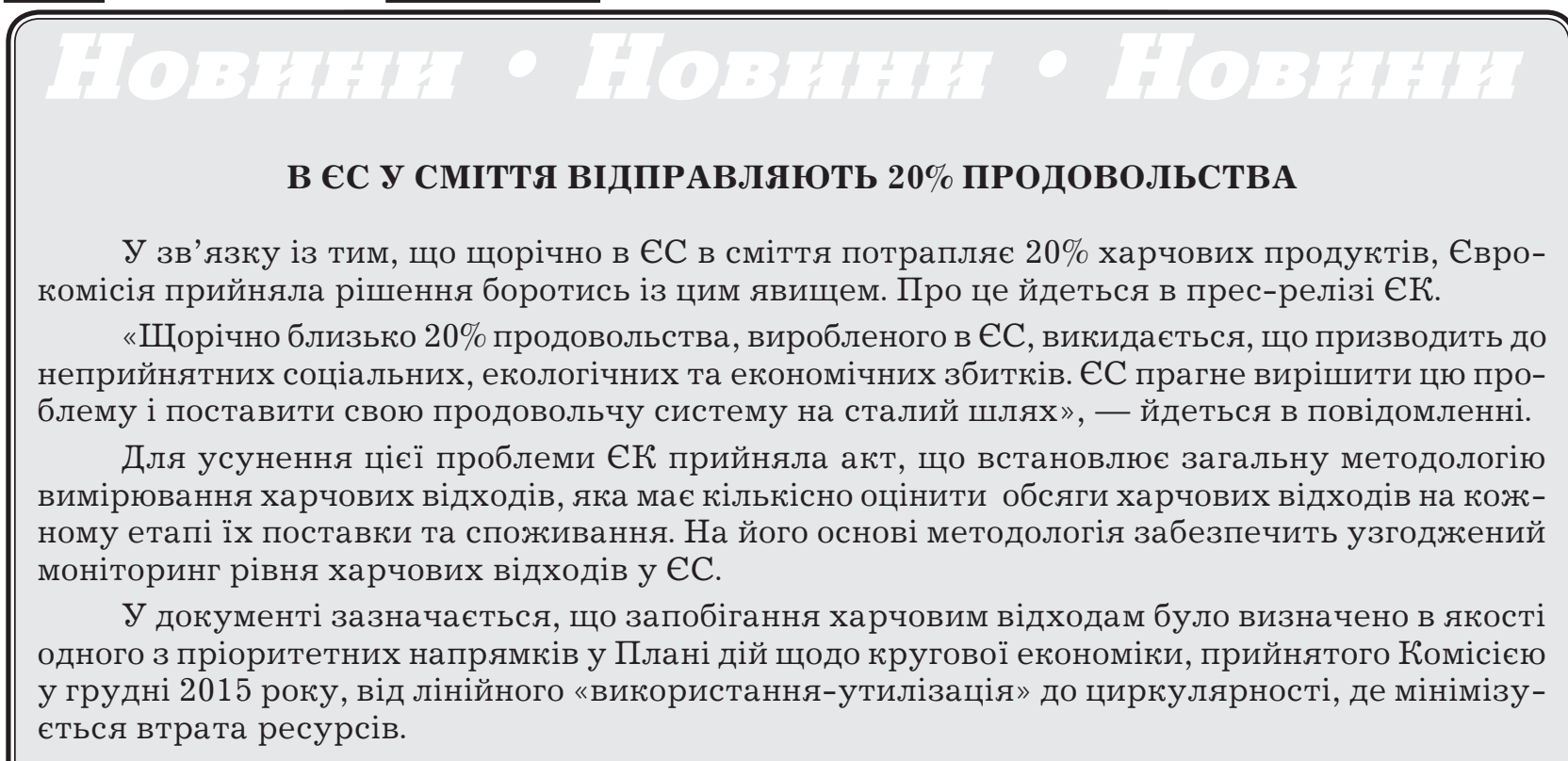

